\title{
The Effect of PORPE (Predict, Organize, Rehearse, Practice and Evaluate) Strategy towards Reading Comprehension
}

\author{
Efa Silfia $^{1}$
}

${ }^{1}$ Universitas Batanghari

\section{ARTICLE INFO}

\section{Keywords:}

PORPE

Reading Comprehension

\begin{abstract}
Reading comprehension is the message that is imposed in the written form. It is most important element that students must recognize, because the primary purpose of reading comprehension is to know the way in getting what the students want to know from reading material. In fact, most of the students got difficulties to understand reading text because they think that answering reading is not interesting task and not explicitly stated on the text. The aim of this research is to find out whether any significant effect of using PORPE toward reading comprehension. The research used experimental method. The population was students at Eleventh grade in SMAN 3 Kota Jambi. The sample was divided into two randomized group: XI IPA 1 as experiment class and XI IPA 2 as control class. The instrument of the research had been done in reading comprehension test. The data of the research showed that after counting the students' scores and analyzing by using t-test formula, the result of experimental class was significantly higher than the students' score in control class. It was showed at the level of significance 0.05 with the degree of freedom $(\mathrm{df}) 60$, $t$-observed value $2.512>t$ table value 2.000 . The null hypothesis (Ho) was rejected and alternative hypothesis (H1) was accepted. The conclusion was using PORPE strategy affected the students' reading comprehension.
\end{abstract}

\section{INTRODUCTION}

Reading is an important part in English, it is not only to gain information from written sources but also as a way to know how the native speaker use their language in writing. Moreover, reading is also important in teaching and learning process because the ability of student in understanding the subject depends on their reading skills. For these reasons, reading should be emphasized to be effective activity. In reading comprehension, the message to be imposed in the written form is the most important element that the students must recognize, because the primary purpose of reading is to know the ideas expressed in the printed material. Therefore, reading with comprehension is

\footnotetext{
${ }^{1}$ Corresponding author's address: Universitas Batanghari, Indonesia

e-mail: efasilfia28@gmail.com
} 
only a way for the students to get what they want to know from the reading material. However, the problem is how to make them comprehend.

According to Whorter MC and Kathlean in Adriyanto (2005: 2) reading is an active process to identify an important idea. Therefore, in reading activity the readers have to look the main idea of each paragraph and try to compherend the reading material because without comprehending the main idea of each paragraph could make them difficult to understand what they have read and they don't know what the writer means in reading material. This statement is supported by Adriyanto (2005: 2), he states that there are two important factors to help students get success in reading. They are internal and external factors. Internal factor means everything that comes from inside the readers themselves, that can motivate and push them to read and interact in reading process. Meanwhile, the external factor means everything from outside including the environment of the readers that can help them learn.

Based on observation, there were problems that the researcher found. Teaching and learning reading are not easy matter but they are the complex process. It is not only involve the students' ability to read the text, but also the readers' ability to understand the text. Many students think that reading is boring activity. Most of the students think that answering reading test is a boring task. They feel bored and lazy to find the answer of reading test because they had to read more, especially if the answer were not explicitly stated on the text. Moreover, the students often got bored with the class, got difficulties to understand reading text, and they did not concentrate during learning reading comprehension.

The problems can not only be attributed to the students' personal factors but also teacher's factor such as unused interesting and suitable strategy in teaching and learning process. In the case teacher had to find out good strategy that can make students interest in learning reading. Looking at the fact, it is necessary to hold a learning improvement. One strategy that can be used in reading comprehension learning is PORPE strategy. This strategy includes 5 (five) stages, namely Predict, Organize, Rehearse, Practice and Evaluate. Abidin (2012: 3) states that PORPE is a strategy which operates the cognitive and metacognitive processes that make effective readers engage in understanding material. By using PORPE strategy, the students are expected to be an effective reader who clarify the purpose of reading, identify the important aspect of message, focus attention on the major content, monitor ongoing activities, engage in self-questioning to determine whether goals are being achieved, and take corrective action in understanding.

Based on explanation above, the researcher conducted the research about a learning strategy learning reading to see the effect of PORPE towards students' reading comprehension.

\section{METHOD}

The design of this research was experimental research. It used quasi experimental design that is to approximate the condition of an experiment in a setting which does not allow the control and manipulation of all relevant variables. It aimed to find out effectiveness of the use of PORPE strategy to see the effect on students' reading comprehension at the eleventh grade students of SMAN 3 Kota Jambi.

The population of this research was eleventh grade students of SMAN 3 Kota Jambi. There were 4 (four) classes with the total number of 157 students. The sample of this research was chosen by cluster sampling. As mentioned by Arikunto (2007: 101) if the population less than 100, it is better to take members in population as sample. But if the population is more than 100, the sample can be taken $10-20 \%$ or $20-25 \%$ or more. Because the population of this research was more than 100 , the research used cluster sampling to choose the sample.

The instrument of the research was reading comprehension test. The researcher used multiplechoice items. The text consisted of narrative text entitled Benjamin Franklin, Snow White, Pinocchio, 
Romeo and Juliet, The Legend of Surabaya. There were 25 items for pre-test and post-test. For making the questions, the researcher followed the indicators in reading called literal comprehension. According to Nunan (1995: 132) reading test is consisted of some points on the level comprehension. Literal comprehension consists of finding based on the level of comprehension consists of finding explicit information (detail information), identifying topic and main ideas and vocabulary items. In this research, the researcher used the indicators such as main idea, factual information and detail information, reference word, vocabulary items, generic structure and language use of narrative text.

In collecting data, the researcher used pre-test. It was taken before presenting the treatments to know how far the students' reading comprehension skill of English lesson in eleventh class. The type of pre-test was objective test. It consisted of multiple choice forms. Then, post-test was given to the students in order to know the progress students' in reading using PORPE strategy after treatment. The type of the test was objective test. They were multiple-choice forms. The items of post-test were related to the material that the students learned. The materials were given to the students based on the basic course outline which is designed by the department of education in curriculum 13. The two groups got the same material. The material was taken from the book entitled Look Ahead an English course 2.

The data were analyzed in using interpretation of the data collection. The researcher got the data from the pre-test and post-test result after the students got the treatment. Then the scores of both test were tested by using t-test formula. There were some formulas to know the result of t-test. It was done to see the differences between the experimental and control classes. Here is the formula of t-test proposed by Sugiyono (2008: 274):

$$
t=\frac{X_{1}-X_{2}}{\sqrt{\left(\frac{s S_{1}+s s_{2}}{n_{1}+n_{2}-2}\right)\left(\frac{1}{n_{1}}+\frac{1}{n_{2}}\right)}}
$$

Where:

$\mathrm{t}=\mathrm{T}$-test

$X^{1}=$ Score of post-test in experimental class

$X^{2}=$ Score of post-test in control class

$S S_{1}=$ The deviation of Experimental class

$S S_{2}=$ The deviation of control class

$n_{1}=$ Number of sample in experimental

$n_{2}=$ Number of sample in control class

To find the result difference of $\mathrm{t}$-table is compared to t-test. It is assumed that there is an effect of PORPE strategy for reading comprehension of students if the t-test is bigger than $t$-table. In contrary, there is no effect of PORPE strategy for reading comprehension of students if the $t$-test less than $t$ table.

\section{RESULT AND DISCUSSION}

\section{Result}

Before conducting the research, the previous researcher made one class as a try out class. The researcher did one test in the try out to ensure the validity of the items. After doing the try out test, the researcher got the results from the answers of each student who joined the try out. It meant that the items that could be used in research were 30 items. Then it was found that the highest score of 
students was 86.66 and the lowest score was 43.33 . There were 4 students in very good category $(10 \%), 15$ students $(37.5 \%)$ in good category and 21 students $(52 \%)$ in fair category. The average value of students who joined the try out was 63.22.

\section{The result of pre-test in experimental and control class}

In experimental class, there were 40 students' score taken for the test data. The pre-test result showed that the mean score of data was 61.41. From the pre-test result it can be seen the lowest score was 40 and the highest score was 83.33 .

Table 1

The distribution of the pre-test in experimental class

\begin{tabular}{|c|c|c|c|}
\hline \multirow[t]{2}{*}{ Score } & \multirow[t]{2}{*}{ Category } & \multicolumn{2}{|c|}{ Pre-test } \\
\hline & & Frequency & Percentage \\
\hline $81-100$ & Very good & 1 & $4.5 \%$ \\
\hline $61-80$ & Good & 19 & $47.5 \%$ \\
\hline $41-60$ & Fair & 19 & $47.5 \%$ \\
\hline $21-40$ & Weak & 1 & $4.5 \%$ \\
\hline $0-20$ & Poor & - & - \\
\hline \multicolumn{2}{|c|}{ Total } & 40 & $100 \%$ \\
\hline
\end{tabular}

From the table 1, the pre-test result in experimental can be seen that there was 1 student $(2.5 \%)$ in very good category, 19 students $(47.5 \%)$ were in good category, 19 students were in fair category, 1 student $(2.5 \%)$ were in weak category, and no students in poor category.

Then, the result of pre-test in control group showed that the lowest score is 40 , the highest score is 83.33 and the mean score is 62.99 .

\section{Table 2}

The distribution of the pre-test in control class

\begin{tabular}{|c|c|c|c|}
\hline \multirow[t]{2}{*}{ Score } & \multirow[t]{2}{*}{ Category } & \multicolumn{2}{|c|}{ Pre-test } \\
\hline & & Frequency & Percentage \\
\hline $81-100$ & Very good & 1 & $2.5 \%$ \\
\hline $61-80$ & Good & 21 & $52.5 \%$ \\
\hline $41-60$ & Fair & 16 & $40 \%$ \\
\hline $21-40$ & Weak & 2 & $5 \%$ \\
\hline $0-20$ & Poor & - & - \\
\hline \multicolumn{2}{|c|}{ Total } & 40 & $100 \%$ \\
\hline
\end{tabular}

From the table 2 above it can be seen that pre-test in control group, 1 student $(2.5 \%)$ is in very good category, $21(52.5 \%)$ students in good category, $16(40 \%)$ students in fair category, $2(5 \%)$ students in weak category and no students in very good category. In the control class the researcher did not give special treatment such as giving treatment like the researcher did in the experimental class. 


\section{The result of the post-test in experimental and control class}

After four meetings, it can be seen the results of the implementation of the PORPE strategy at the fourth meeting. The Post test result in the Experimental group shown that the mean score of post test result is 72.58 , there were 40 students' score of post test result with the lower score was 53.33 and the highest score was 90 . There are 6 students $(15 \%)$ in very good category, 29 students $(72.5 \%)$ are in good category, 5 students $(12.5 \%)$ are in fair, and no students is in weak and poor category. Table shows the score distribution of post-test in experimental class.

Table 3

The distribution of Post-test in experimental class

\begin{tabular}{|c|c|c|c|}
\hline \multirow[t]{2}{*}{ Score } & \multirow[t]{2}{*}{ Category } & \multicolumn{2}{|c|}{ Pre-test } \\
\hline & & Frequency & Percentage \\
\hline $81-100$ & Very good & 6 & $15 \%$ \\
\hline $61-80$ & Good & 29 & $77.5 \%$ \\
\hline $41-60$ & Fair & 5 & $12.5 \%$ \\
\hline $21-40$ & Weak & - & - \\
\hline $0-20$ & Poor & - & - \\
\hline \multicolumn{2}{|c|}{ Total } & 40 & $100 \%$ \\
\hline
\end{tabular}

After four meetings in two months, the results of the post-test for the control class were obtained, in which the meeting schedule was explained in the previous table. For Post test result the lowest score is 40 , the highest score is 86.66 and the mean score is 67.33 presented the complete result of the test. There is 1 student $(2.5 \%)$ in very good category, 29 students are in good category, 9 students $(22.5 \%)$ are in fair category, 1 student $(2.5 \%)$ in weak category and no students in poor category. It can be seen from the table 4 :

Table 4

The distribution of post-test score in control class

\begin{tabular}{|c|c|c|c|}
\hline \multirow[t]{2}{*}{ Score } & \multirow[t]{2}{*}{ Category } & \multicolumn{2}{|c|}{ Pre-test } \\
\hline & & Frequency & Percentage \\
\hline $81-100$ & Very good & 1 & $2.5 \%$ \\
\hline $61-80$ & Good & 29 & $52.5 \%$ \\
\hline $41-60$ & Fair & 9 & $22.5 \%$ \\
\hline $21-40$ & Weak & 1 & $2.5 \%$ \\
\hline $0-20$ & Poor & - & - \\
\hline \multicolumn{2}{|c|}{ Total } & 40 & $100 \%$ \\
\hline
\end{tabular}

\section{Discussion}

Based on the researcher's finding, there is a difference between score of pre-test and post-test. The pre-test score is lower than post-test. It means that PORPE strategy gives effect on students' ability to read and not only can read but also understand well so that they are able to answer questions with better score than using common strategy. It has related with developed theory by Simpson (in 
Zuchdi, 2011: 120) namely: Predict (predict), Organize (organization), Rehearse (practice), Practice (practice), and Evaluate (evaluate).

Supported by Simpson, Stahl and Hayes (1989: 22), he said that when students follow the steps of PORPE as they read and study, they behave like "effective readers", Baker and Brown's (1984) who encode information and regulate their own learning. Supported by Simpson (1986: 22) said that PORPE could give effect on students' ability in reading comprehension, it shows that PORPE does have important advantages for long term learning and students' independence.

From the first observation, there was good cooperation with the staff, teachers, and students. They had good learning facilities in the classroom and the researcher immediately came to try out class, then determined the Control class and the Experimental class. From the second observation, the researcher already knew the control class and experimental class and then began teaching. I saw students who had good preparation to start studying, and they were honor persons.

In pre-test of control class, the researcher found if students were likely bored and not interested to the text that has been presented with the common strategy. There was no new motivation happened in this class, because did not really understand about the content of the text. Moreover, in control class, common strategy was given as a treatment. Before the treatment was given for this group, the pre-test showed that the lower category was weak and the highest category was very good with 2 students $(5 \%)$ were in weak category and 1 student $(2.5 \%)$ was in very good category. But after treatment was given, the post-test result showed that there was 1 student $(2,5 \%)$ in weak category and 1 student $(2,5 \%)$ for very good category, there was improvement from 2 students (5\%) becomes 1 student $(2,5 \%)$. It can be seen that the students' ability in reading comprehension was increased by using common strategy but increasing was only little than using PORPE strategy.

In experimental class, before the treatment was given for this class, the pre-test result showed that the lower category was poor and the highest category was very good with 1 student $(2.5 \%)$ was in weak category and 1 student $(2,5 \%)$ was in very good category. But after treatment was given, the post test result showed that the lower category was fair and the highest category was very good. There were 29 students for good category $(72.5 \%)$ and 6 students (15\%) for very good category, there was improvement from 19 students $(47.5 \%)$ becomes 29 students $(72.5 \%)$, it can be seen there were no students in poor category. So it was concluded that PORPE Strategy gave much increasing on students' ability in reading comprehension.

There were differences between two classes. The value of t-test is higher than t-table. It indicated that increasing, that using PORPE Strategy had given a positive contribution in Reading Comprehension especially on the eleventh grade of science class of SMAN 3 Kota Jambi at XI IPA 1. To see the mean different score of pre-test and post-test, it can be seen in the following table:

Table 5

The mean of pre-test and post-test in Experimental and Control class

\begin{tabular}{cccc}
\hline Class & Pre-test & Post-test & Difference \\
\hline Experimental class & 61.41 & 72.58 & 11.17 \\
Control class & 62.99 & 67.33 & 4.34 \\
Difference & 1.58 & 5.25 & 4.23 \\
& & & \\
\hline
\end{tabular}

From the table 5, it can be seen the mean score of pre-test in experimental class was 61.41 and the mean score in post-test was 72.58 the difference was 11.17. While, mean score of pre-test in control 
class was 67.33, and the difference was 4.34 . The differences between mean score of pre-test in experimental and control class was 1.58 and the differences of mean score of post-test between posttest in experimental and control class was 5.25.

\section{CONCLUSION}

Based on the result and discussion above, it can be concluded that PORPE strategy had significant effect on students reading comprehension of eleventh grade students of science at SMAN 3 Kota Jambi. First, the analysis indicates the mean score of students' reading comprehension by using PORPE strategy was higher than the mean score of student's reading comprehension without using PORPE strategy. In the pre-test of experimental class, the students mean score was 61.41 and posttest was 72.58. The scores of the students give effect significantly because the students enjoy and free to expressed their idea. Meanwhile, in the post-test, it was 67.33 it means that there was an improvement in students reading comprehension score.

From the t-test result, it was found that the score was 2.512 and t-table 2000 because of the result of t-test was higher than $\mathrm{t}$-table, it indicated that hypothesis was rejected and research hypothesis was accepted. It can be concluded that there was a significant effect of using PORPE strategy toward students reading comprehension. It means that PORPE can be applied as one of alternative way to give effect on students reading comprehension at SMAN 3 Kota Jambi.

\section{REFERENCES}

Abidin, Y. (2012). Pembelajaran membaca berbasis pebndidikan karakter. Bandung: PT Refika Aditama.

Adriyanto, H (2005). Improving reading comprehension of the second year students of SMA Negeri 1 Manjang Pajo through Listen - Read - Discuss method. Thesis: FBS UNM.

Arikunto, S. (2007). Prosedur penelitian: suatu pendekatan praktik. Jakarta: Rineka Cipta.

Baker L. , Brown A. L. (1984). Metacognitive skill and reading. In Pearson P. D. (Ed), Handbook of reading research (pp.353-394). New York: Longman. Available online @http://www.jstor.org.edu/porpe.html

Nunan, D. (1995). Second language teaching and learning. Bolton Massachusetts USA: Heinle \& Heinle Publisher.

Simpson, M. (1986). PORPE: A writing strategy for studying and learning in the content areas. Journal of Reading, 29 (5), 407-414. Available online @http://www.jstor.org.edu/porpe.html

Simpson, M. L., Stahl, N., \& Hayes, C. G. (1989). PORPE: A reseach validation. Journal of Reading, 33, 22-28.

Sugiyono. (2008). Metode penelitian kuantitatif, kualitatif dan RED. Bandung, Alfabeta.

Zuchdi, D. (2011). Strategi meningkatkan kemampuan membaca peningkatan komprehensi. Yogyakarta: UNY Press. 